\title{
The exploration of Problems and Reflections in the Japanese Literature Teaching
}

\author{
Rizhong Shen ${ }^{1, a}$ \\ ${ }^{1}$ Quanzhou Normal University, Quanzhou, Fujian Province, China \\ aqztcshenrizhong@hotmail.com
}

Keywords: Japanese literature, Japanese teaching, Teaching problem, Thinking

\begin{abstract}
Japanese classroom teaching is an important position to improve students' interest in learning Japanese literature and the key to improving the quality of Japanese literature. How teachers teach in the classroom, how students learn in class, has been an important issue for researchers to explore. In recent years, the Japanese literature classroom teaching has been reformed and summarized, received good results, but there are still many problems, this article on these issues for simple analysis, and targeted to solve the problem.
\end{abstract}

\section{Introduction}

At present, there is a growing number of Chinese Japanese learners, including Japanese students and Japanese interested students. Today, Japanese literature education is booming in China. Japanese has become the second largest foreign language in China after English. The development of Japanese literature education is mainly driven by two aspects. First of all, by the international cooperation and the impact of international trade, since the reform and opening up, China and international cooperation and exchanges are deepening, especially with Japan in the economy, trade exchanges increasingly frequent [1]. This requires a large number of Japanese learners involved, which is leading to the development of Japanese literature education the primary factor. In addition, the exchange of culture and technology makes China and Japan exchange students become more and more.

In the whole Japanese literature education, Japanese grammar education has a very important role. On the one hand, Japanese grammar education is the foundation of Japanese literature education. Grammar learning is the cornerstone of learning and using the whole Japanese. Any language learning, no doubt from the grammar began. Grammar is the basis for written expression, while grammar ability is a guarantee of verbal expression of the tool. On the other hand, grammar is the sum of morphological changes and the rules of words. It is absolutely necessary to teach students the basic knowledge of grammar, to understand grammar law rationally and to guide the practice of language through grammar teaching.

\section{The Main Problems in the Teaching of Japanese Literature}

The main problems that have affected and hindered the improvement of the quality of Japanese classroom teaching are:

Spoon type. Some teachers are in school when the endless, blackboard written full and students keep notes. This kind of full house is irrigation, spoon-fed approach to bring a lot of ills. Teachers can speak too much, he can provide students with independent knowledge, independent thinking, active training ability of the less chance, students often in a passive position, there is no time to think, digest, absorb, knowledge of course cannot be consolidated [1]. Again, talk too much, the focus is not prominent, students cannot grasp the essentials, classroom atmosphere is also boring, students prone to fatigue.

Old style. Some teachers stay in the original state of teaching, no language room, no slides, no computer and other modern means to assist in teaching, and even the tape recorder are less used, from beginning to end by the teacher only, simply cannot afford Students interested in learning. 
Test form. Students to participate in the examination and college entrance examination, only written test, do not assess the students listening and speaking ability. In order to meet the requirements of student responses, many teachers do not pay attention to listening and speaking training, students full of brains are full of grammar, sentence patterns and rules, poor ability to hear.

Weary style. Some teachers cannot thoroughly grasp the teaching materials, dealing with the lack of flexibility in teaching, teaching methods, not good at learning the strengths and update the knowledge of others, over the years to repeat this teaching, tired. In addition, some teachers teaching tasks, both when the class teacher, but also teach a few classes, as well as in the college entrance examination pressure, one day busy with teaching and other affairs, over time, but also prone to boredom.

Tired of school style. Students learn rote; some students do not even know the phonetic, not spelling words. Often in accordance with the alphabetical order of words, like reading the phone number as repeated recitation, writing new words [2]. As a result, students' "hard study" cannot receive the desired results, learned the words are not allowed to read, the new words will not read, plus too much work, the more learning more difficult, will be psychological fear, Disgust or even contradictory mood.

Mother tongue. Some teachers use the mother tongue teaching, the Japanese literature teaching into Chinese teaching. In the first foreign language teaching, because the teaching content is shallow, easy to understand, easy to use intuitive means of teaching, do not have to use the mother tongue translation. But in high school, some teachers are also used to teach and explain in their native language, the atmosphere of learning foreign language in the senior, has not yet formed well.

Japanese literature classroom teaching concept behind. For a long time, foreign language teachers and foreign language workers have always attached importance to the study of teaching methods, while ignoring the study of law, there are still many foreign language teachers believe that learning foreign language have to rely on rote and no other way. Therefore, students lack scientific learning methods. For example, the current teaching materials, regardless of "Oxford", or "new century", the vocabulary is very large [2]. Many students cannot skillfully and accurately spell the word, the ability to remember the word is poor, the difficulty of learning the word so that they learn to stop, and even learn to fall behind, gradually lost learning Japanese literature interest and confidence. It can be said that the cultivation and guidance of teachers 'learning methods is an important reason for students' learning disabilities and polarization.

\section{The Reasons for the Problems in Japanese Literature Teaching}

The main problems of the above-mentioned Japanese literature classroom teaching are more complicated. There are objective reasons; there are subjective reasons, the specific performance in:

Teachers are accustomed to using traditional teaching methods. The most notable feature of traditional teaching methods is the uses of spoon-fed and backward teaching methods, because this traditional teaching method is simple and easy, do not have to use brains and the use of advanced teaching equipment, you can teach [3]. Although some schools lack of advanced teaching equipment, but some teachers in order to simple and easy way, do not seriously think about teaching reform problems, do not want to move teaching equipment, relying on a book, a few chalk and a mouth on the Japanese language teaching, So that students in the lack of advanced teaching equipment and means of the classroom can only be passive to accept inculcation.

Follow the test of the baton to go. Although the student test scores are an important basis for examining the teaching effect of teachers and students' academic performance, but in order to take a simple examination, teachers are teaching and learning in the students, only focus on guessing and written practice, ignoring the Japanese literature Teaching, comprehensive basic knowledge teaching and comprehensive ability training. And some only focus on graduating class, grasping key classes and grasping the top students, the result is focused from the beginning of a large area to improve the quality of students learning Japanese literature become empty talk.

Teacher teaching and student learning tasks are too heavy. In the teaching of teachers, due to the relative lack of Japanese school teachers in some schools, the number of teachers on the number 
of classes, the task of correcting the job is very heavy, teaching tasks only stay in the completion of the number of hours, no energy to study the quality of teaching, class content back and forth, Resulting in teachers have a sense of tiredness [2]. Students learn, because students learn monotonous, cannot grasp the new knowledge, every day to complete a lot of homework, the students feel the pressure is heavy, but also make students wear tired of learning emotions.

Foreign language teaching with mother tongue. Japanese literature should try to cultivate students' Japanese literary thinking, that is, to use Japanese literature to explain, but some teachers that students do not understand and do not understand, in addition to reading the text is read in Japanese literature, the rest of the classroom is basically used to explain Chinese to explain, over time, the students cannot improve the hearing.

The enthusiasm of students to learn Japanese literature is not fully mobilized. Students in the study of Japanese literature, the purpose is not clear enough. At the beginning of the study of Japanese literature, feel fresh and under a certain effort, but learning a long time, they feel boring. Coupled with the teacher in the teaching is not well guided, resulting in the enthusiasm of students to learn Japanese literature is not fully mobilized.

\section{Measures and Countermeasures to Improve Japanese Literature Teaching}

It is important to take appropriate measures to overcome the main problems existing in the classroom teaching of Japanese literature in middle school, which will play an important role in improving the quality of Japanese classroom teaching and improving the interest of students in learning Japanese literature. I believe that should start from the following aspects:

Fine talk more practice, guide combination. In order to enable students to learn the content of a clear, deep impression, to live and use, arouse students' interest, active classroom atmosphere, in order to improve the classroom teaching effect [3]. For example, in the reflexive pronoun of this speech, the first clear purpose of teaching, is to allow students to learn seven reflexive pronouns and as the main language of the main language usage, and then according to the degree of acceptance of students to determine the degree of teaching.

Strengthen the construction of Japanese literature teaching equipment, the use of advanced means to organize teaching. Today's society is the era of rapid development of science and technology, Japanese literature teaching still remain in the original state of teaching, cannot meet the requirements of the development of the times [3]. Now some developed countries, language teaching, generally using advanced teaching methods, not only through the language room equipment, slides, tape recorders, video recorders to assist teaching, but also the use of computer teaching methods, computer test methods and so on. This advanced teaching equipment, especially computer teaching methods and computer examination methods, in Chinese middle school Japanese literature teaching, has not been popularized. In order to improve the quality of Japanese literature in high school, it is necessary to strengthen the construction of Japanese literature teaching equipment and adopt advanced equipment to organize teaching.

Take a flexible and diverse teaching method to cultivate students' interest in learning. To make students learn to learn motivation, light the truth, a clear purpose of learning is not enough, teachers must also make their own class interesting, to attract students, so that students maintain a strong interest in learning [4]. For students of the beginning grade, interest is power. Cultivating interest in learning is a way for students to love this discipline, and good teaching methods are an important factor in stimulating interest. Teach boring, will not learn. Students' interest in learning is largely from the teacher's subjective effort, which requires teachers to continue to observe and summarize, to cultivate learning interest throughout the teaching process. Teachers should pay attention to two aspects of the work: First, the lesson plan to meet the actual situation of students, careful consideration of their knowledge will be in the minds of students get what kind of understanding and according to this feature to determine the teaching method, and strive to achieve the unity of teaching and learning.

Establish a harmonious relationship between teachers and students to create a harmonious atmosphere of the classroom. The harmonious relationship between teachers and students helps to 
create a harmonious classroom atmosphere, which requires teachers to make positive efforts in the subjective. Teachers should be students' intimate people, to understand their psychological characteristics, care about their learning, physical and mental health, understanding their difficulties in learning Japanese literature, good at inspiring them.

Teach students to learn ways to cultivate students' self - learning ability. Teachers to teach students not only to impart knowledge, but also pay attention to teach self-learning methods, to teach students to check the dictionary; to help students master the plural, the third person singular form of the law; with graphic help students understand the current time, and other grammatical content; To help students have a good sound mark off, with the pronunciation rules to spell words; insist on the students in the new on the new words to learn the book, at any time to write down the word synthesis, transformation, derivative words and antisense, near meaning, homonym; Before class, listen to the recording, imitate the correct voice tone and so on [4]. In the high school stage, students develop the ability to spell words, construct the word analysis ability and the ability to infer; help the learners have the ability to demonstrate, general ability and reading ability; and improve students' ability to analyze syntactic. In the ability to parse the syntax to remind students to correct understanding, otherwise it is inevitable that the difference between the least, lost thousands of miles. Therefore, it is very important to cultivate students' syntactic ability

Educational thought: change "to Japanese literature as the" as "people-oriented". People-oriented, that is, the overall quality of people-oriented, people's sustainable development-oriented; training is a sound personality and sustainable development of the integrity of the people, rather than simply focus on how much of his now grasp the word and sentence [1]. The First adult, after the talent, Japanese literature education is equally duty-bound to bear this historical mission.

Over the years, many teachers have used a lot of facts to prove that Japanese literature teaching itself not only should bear the language of teaching tasks, but also and should be able to bear the students in the following seven aspects of the basic quality and development of educational capabilities. The seven aspects are: ideological and moral, psychological quality, thinking quality, personality quality, cultural literacy, learning ability, social ability.

Teaching principles: change the "teacher-centered" as "student-centered." The essence of quality education is human subjectivity. Subjectivity is the fundamental requirement of quality. The main mechanism of quality education is internalization mechanism. In other words, the quality of people is based on the formation of their own internalization [3]. Students are the subject of thinking that no one can replace. Japanese literature is a very practical technical disciplines, Japanese literature is the students themselves will practice, rather than teachers talk about.

Use multi - resources to improve teaching effectiveness. With the improvement of school conditions, multimedia equipment to become teaching resources, public Japanese teaching should also use these resources to assist teaching. In addition, students who can organize public Japanese students and professional Japanese students become "conversational partners", giving them the opportunity to apply knowledge to practice and enhance the confidence of communication.

Teachers to adapt to the new curriculum, change the concept is the premise. Teachers want to change their role. The new curriculum emphasizes that teachers are students of teach partners, guides and participants; the teaching process is the interaction between teachers and students, the common development process [4]. Communication means that everyone is involved, means equal dialogue, and the teacher will be condescending authority to "equality in the chief." In the new curriculum, the traditional sense of teaching and student learning, will continue to let teachers and students learn each other, each other to form a real "learning community", but also teachers and students to develop courses, enrich the course process, Curriculum into a dynamic, development, teaching truly become teachers and students of the creative process of creation. The role of teachers in the classroom directly affects the teaching effect [4]. In accordance with the requirements of the new curriculum, teachers should help students develop appropriate learning objectives and identify and coordinate the best way to achieve their goals; to guide students to form a good learning habits, master learning strategies; create a rich teaching environment, to stimulate students' learning motivation, To cultivate students' 
interest in learning; to provide students with a variety of facilities for the students to learn services; to establish an accepted, supportive, tolerant classroom atmosphere; as learning participants, and students to share their feelings and ideas; and students To find the truth, and to admit their mistakes and mistakes. So how does the promoter's role play?

\section{Summary}

Teachers are the key factors to promote curriculum reform, it is necessary through a variety of ways to give teachers "brainwashing." The student's learning process is both a process of cognition and a process of inquiry. The process of education is a kind of exploration and creation. The classroom teaching of Japanese literature only has the main role of the student and the teacher's leading role is well unified, and constantly explores the new ideas and new methods of classroom teaching, guiding students to discover, explore and solve The ability of the problem, in order to cultivate students' pioneering spirit and innovative consciousness, and gradually cultivate their ability to create different ... Our teachers have to constantly in their own teaching process to sum up and innovate.

\section{References}

[1] Y.M. Shen, Japanese literature education, Foreign literature education, 2004, vol.4, pp.84-87.

[2] W.W. Hu, New ideas of Japanese grammar teaching mode, Journal of Southwest Agricultural University, 2013, vol.7, pp.86-89.

[3] L.T. Wang, On the study of Japanese grammar teaching, teaching practice research, 2011 vol.4, pp.31-35.

[4] Y.J. Duan, The Importance of Importing Japanese University Literature Education, Journal of Economic Research, 2012, vol.4, pp.19-23.

[5] P.X. Zhang and Y.Ch. Wu, Nearly 10 years domestic Japanese teaching research status quo, Japanese learning and research, , 2014.vol.8, pp.21- 25. 